\title{
Physico-Chemical and Microbiological Analysis of Borehole Water Sources in E-One Estate Lemna, Calabar, Cross River State, Nigeria
}

\author{
Ebin Okah Inah ${ }^{1}$, Josiah Nwabueze Obiefuna ${ }^{2 *}$, Etim Omini Eteng ${ }^{3}$, Iheoma Iwuanyanwu ${ }^{4}$, Bello, A. A. ${ }^{5}$ \\ ${ }^{1}$ Department of Geography and Environmental Science, Faculty of Environmental Sciences, University of Calabar, \\ P.M.B. 1115, Calabar-Nigeria. Email: ebin.inah@unical.edu.ng \\ ${ }^{2}$ Department of Geography and Environmental Science, Faculty of Environmental Sciences, University of Calabar, \\ P.M.B. 1115, Calabar- Nigeria. Email:JoeObiefuna@Unical.edu.ng \\ ${ }^{3}$ Department of Geography and Environmental Science, Faculty of Environmental Sciences, University of Calabar, \\ P.M.B. 1115, Calabar-Nigeria. Email: Etimeteng89@gmail.com \\ ${ }^{4}$ Department of Geography and Environmental Science, Faculty of Environmental Sciences, University of Calabar, \\ P.M.B. 1115, Calabar-Nigeria. Email: Omaiwuanyanwu@ yahoo.com \\ ${ }^{5}$ Department of Geography and Environmental Science, Faculty of Environmental Sciences, University of Calabar, \\ P.M.B. 1115, Calabar- Nigeria. \\ *Correspondents: JoeObiefuna@Gmail.com, JoeObiefuna@Unical.edu.ng
}

Received Date : December 31, $2021 \quad$ Accepted Date : January 27, $2022 \quad$ Published Date : February 07, 2022

\begin{abstract}
The study examined the physico-chemical and microbiological parameters of boreholes water sources in Eone estate in Lemna, Calabar municipality, Cross River State, Nigeria. Fifteen (15) boreholes were identified and geo-referenced with the help of a global positioning system (GPS). Data were further processed in ArcGIS by overlaying the location on the study area map. Water samples were collected and analyzed for water quality parameters such as dissolved oxygen (DO), potential of hydrogen (PH), biological oxygen demand (BOD), chemical oxygen demand (COD), total dissolved solid (TDS), chlorite, electrical conductivity, fecal coliform, sulphate, nitrate, turbidity, manganese, color and potassium according to [10], and the data form the analysis were analyzed using $\mathrm{t}$-test to determine the significance t-test difference as compared with world health organization (WHO) and the results shows that, BOD $(4.741<\mathrm{P}: 000)$, Chlorine $(87.046<$ P:000), TDS $(2100.679<\mathrm{P}: 1000)$, test $(24.173<\mathrm{P}: 000)$, Sulphate (59.091<P:000), and Turbidity (481.216<P:000). Based on this finding, it is recommended that government should provide pipe born water in the estate, which is always treated and is fit for human consumption, and also the inhabitant should treat their boreholes before it is used for domestic purposes.
\end{abstract}

Key words: Boreholes, Microbiological, Physico-Chemical, Water

\section{INTRODUCTION}

Water is very essential for life, there is great dependence on boreholes due to the absence of surface and pipe sources in E-one estate, the study area is a layout that is demarcated in out-skirts of Calabar Metropolis, and there is no pipe borne water in the layout, since there is understanding that water is purified as it's moves down the aquifer. Water is a major source of the spread of diseases and the fundamental cause of death in developing countries which is as a result of the ability of government to provide portable or make access to quality water to the people.

The physico-chemical parameters have a significant value of water been generally accepted and this study has shown that all the inhabitance of the study area obtained water from boreholes privately own by them, and drinking from such sources without any form of treatment it gives rise to illnesses such as cholera, typhoid, dysentery and so on [1].

In Nigeria, the consumption or use of water from untreated or contaminated sources of water is capable of transmitting water borne diseases. It is based on this observable gap this study is contemplated in E. one estate in Lemna District, Calabar, Cross River State, Nigeria E- One estate has no surface water supply as a means of domestic water use one hundred percent of the people in the estate depend in borehole (groundwater) as a source of water due to nearness. It is important to monitor the quality of the newly drilled ground water in the Estate putting into considering the alarming state of water borne diseases. Therefore, this study aims at analyzing the physiochemical and biological parameters of newly drilled boreholes in the E-One Estate in Lemna, Calabar, Cross River State-Nigeria. The result will be useful to government on the need to make available pipe borne water for the inhabitance of the estate.

Groundwater sources are continuously changing in nature and are influenced by geological processes, urbanization, irrigation activities, industrialization occurring in the area and affecting aquifer minerals, rainfall pattern , rate of infiltration, leaching, pollutant from land surface and the contaminant in turn affect plant growth and human health [2]. Majority of the people in Yakurr depend on streams, springs and ground water for their daily water needs due to inadequate supply of pipe borne water by government and the inability to meet the cost of 
daily buying of water from boreholes which is basically not treated before selling for consumption [2]..

Drinking water sources containing pathogenic micro-organism can cause water borne diseases among the consumers, and the risk of drinking contaminated microbial water is related to fecal coliform contamination as a result of discharging of human and animal waste into water sources [1]. In some developing countries, people have little or no option but adapt to water sources of inferior and doubtful quality, due to lack of better alternative sources, or due to economic and technological constraints to treat the available water adequately before use [2]. The right of every human being is to have access to enough water for personal and domestic uses, meaning between 50 and 100 liters of water per person per clay. The water must be safe, acceptable and affordable; the water costs should not exceed 3 percent of household income [3].

Nigeria is naturally endowed with abundant ground water and surface water resources. However, the socioeconomic activities of communities situated along the stream courses invariably impact on the quality of the stream of the streams. In recent time, due to the increasing demand for potable water in the estate, there is the upsurge in the construction of private boreholes by individuals. This situation is caused by the inability of Government to supply potable water to the people in the area as a. way to meet the increasing water needs of the people. Unfortunately, water from this borehole is pumped and used by the people without any form of treatment. Thus, the rapid expansion in population and the rapid growth in commercial and construction activities in the area made it expedient to investigate the sources of water supply and ascertain their quality.

\section{LITERATURE REVIEW}

Authors [4] examined how human activities impact on lokpoi stream in Cross River State, Nigeria, where water quality parameters were tested like PH,DO, Conductivity, Zinc, Coliform total and fecal coliform where sampled in five locations in the stream channel and compared with world health organization (WHO) and further started that streams are among the most threatening globally and the threat is as a result of uncontrolled human activities like farming, bush burning, flooding due to man's continuous need to satisfy his needs in life and he is gradually destroying the environment which he lives.

An investigation by [2] on the seasonal variation of streams and ground water quality using quality index and he resolved that water supply sources are enormous in Yakurr people but the quality is questionable mostly for domestic purposes and government has made effort established boreholes in the area which eventually dried up during the dry season due to poor drilling depth, the further said that public water supply by water board has never been consistent and very unreliable and the people resort to other sources. Ground water sources are eventually changing in nature as a result of urbanization and geological processes, industrialization and irrigation activities occurring in the area and affecting aquifers, minerals, rainfall patterns, infiltration rate, leaching, pollutants from the land surface and also restricted that boreholes and streams are the main sources of water supply in the area called for concern as the water sources are used by people without any form of treatment. The population depend solely on ground water sources for drinking purposes [5], [6].

According to [7], evaluating the activity of festival activities has so much influence on water quality in Ugep, Yakurr local government area, streams water was sampled and analyzed and questionnaire survey was adopted and randomly distributed by residents during festival period to integrate the socio-economic variable which is the benefits and the problems that is associated with festival and the results presented shows a significant variation with WHO bench mark and indicated that festival has a negative impact on surface water quality in the study area and the socioeconomic indicates that even though festival has socio economically contributed to the wellbeing of the people there are significant problems associated with festival activities that needs urgent attention.

In developing countries like central Africa estimated that more than 2.2 millions of people die each year due to the consumption of unsafe water and inadequate sanitation [8] and that the infections disease related to water and associated parasite account for 60 percent of infant mortality in the world [8]. According to [9] concluded that recently due to high demand potable water there is an upsurge in the construction of bore holes by individuals and this is a result of the inability of government to supply potable water to the people, this leads to indiscriminate sinking of boreholes by private individuals, unfortunately, water from these boreholes is not treated before consumption by the people and some are hygienic because some are in unsanitary areas and some of the containers used for storage are not always clean and some of the contamination are as a result of anthropogenic activities.

\section{MATERIALS AND METHODS}

Prior to sampling collection, fifteen (15) boreholes were identified and their spatial location was documented with the help of global positioning system (GPS), which were later process in ArcGIS 10.5 and overlaid on the study area map. Samples were collected in all the mentioned boreholes as specified by standard bench mark of [10] with plastic bottles, labeled with locations and cork seal and stored in a cool box of $4^{0} \mathrm{C}$ temperature and transported to the laboratory for physicochemical and microbiological parameters analysis. In-situ measurement was conducted in the field on temperature, $\mathrm{pH}$, odour, color taste and turbidity and other parameter like Do, BOD, phosphate, chlorides, sulphates, nitrates, magnesium, hardness, electrical conductivity, total hardness, calcium, total dissolved solid (TDS) and fecal coliform bacteria.

\section{THE STUDY AREA}

E-one estate is in Lemna, Calabar Municipality Local Government Area, Cross River State, Nigeria and is approximately between latitude 5.03872 and $5.043985^{\circ} \mathrm{N}$ of the equator and Longitude 8.362138 and $8.358658^{\circ} \mathrm{E}$ of the Greenwich meridian (Fig 1). It has a total land area of 39.598351 Hectares and the boreholes are located within the estate. 


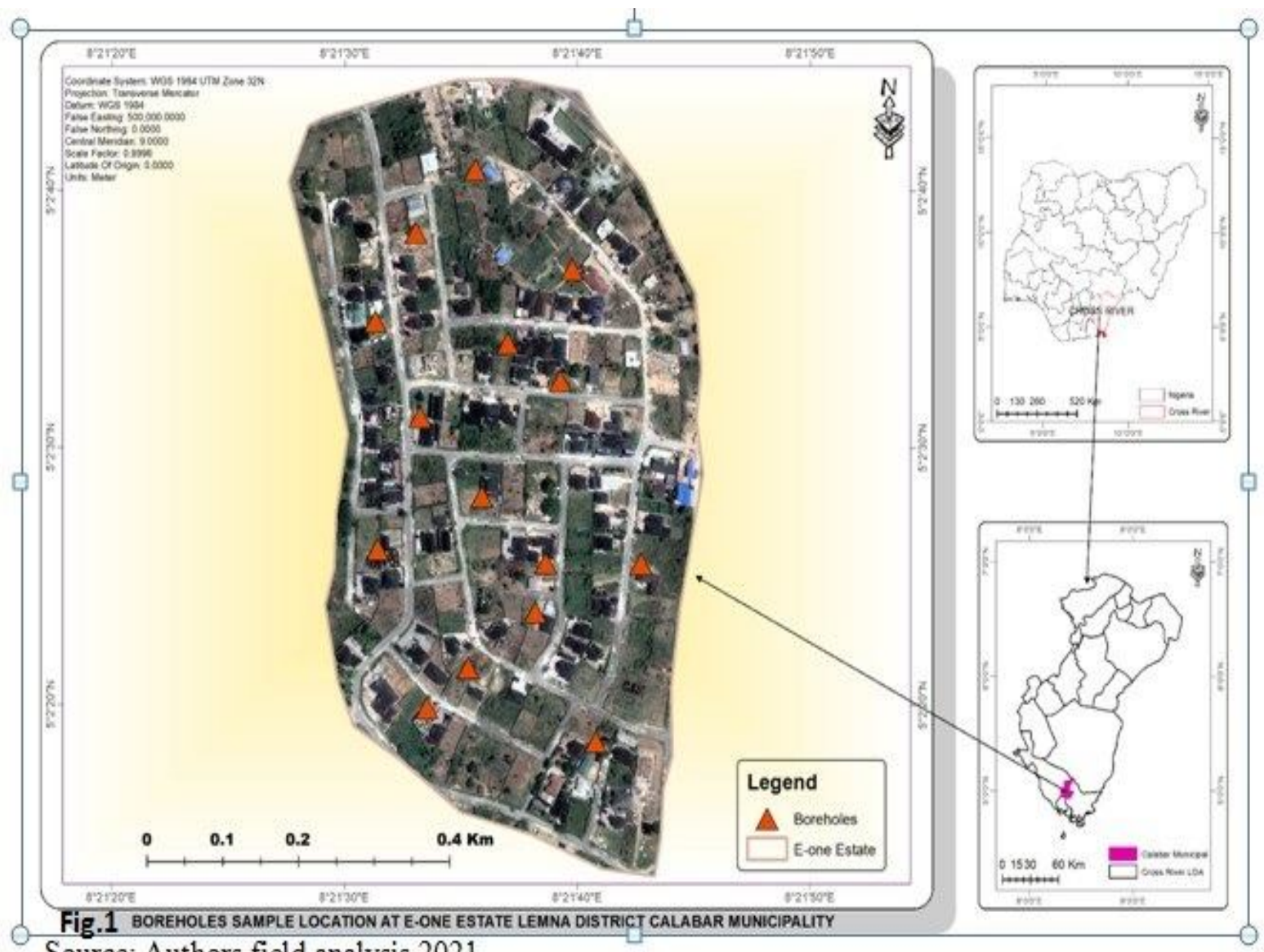

Source: Authors field analysis 2021

\section{RESULTS AND DISCUSSIONS.}

Table 1 : Shows the significant t- difference of B.O.D (4.741<P:000), chlorine (87.046< P:000), TDS (2100.679<P:000) test (42.173<P:000), sulphate (59.091<P:000), turbidity $(451.216<\mathrm{P}: 000)$

Group Statistics

\begin{tabular}{|c|c|c|c|c|c|}
\hline & $\begin{array}{l}\text { BOREHOLE/WH } \\
\text { O }\end{array}$ & $N$ & Mean & Std. Deviation & Std. Error Mean \\
\hline \multirow{2}{*}{ DO } & borehole & 15 & 11.249333 & 19.1330494 & 4.9401321 \\
\hline & WHO Standard & 1 & 30.000000 & & \\
\hline \multirow{2}{*}{$\mathrm{PH}$} & borehole & 15 & 6.745333 & 2.0492294 & .5291087 \\
\hline & WHO Standard & 1 & 6.600000 & & \\
\hline \multirow{2}{*}{ BOD } & borehole & 15 & 2.612667 & .6917314 & .1786043 \\
\hline & WHO Standard & 1 & 6.000000 & & \\
\hline \multirow{2}{*}{ Chlorine } & borehole & 15 & 9.597333 & 2.6740992 & .6904495 \\
\hline & WHO Standard & 1 & 250.000000 & & \\
\hline \multirow{2}{*}{$\begin{array}{l}\text { Electrical } \\
\text { conductivity }\end{array}$} & borehole & 15 & 140.390000 & 71.9117750 & 18.5675405 \\
\hline & WHO Standard & 1 & 100.000000 & & \\
\hline \multirow{2}{*}{ TDS } & borehole & 15 & .468667 & .2302442 & .0594488 \\
\hline & WHO Standard & 1 & 500.000000 & & \\
\hline Fecal & borehole & 15 & 50.383333 & 24.6893160 & 6.3747540 \\
\hline
\end{tabular}


Ebin Okah Inah et al., International Journal of Emerging Trends in Engineering Research, 10(2), February 2022,85 - 90

\begin{tabular}{|c|c|c|c|c|c|}
\hline \multirow{3}{*}{$\begin{array}{l}\text { coliform } \\
\text { T.TL }\end{array}$} & WHO Standard & 1 & .000000 & \multirow[b]{2}{*}{11.0132835} & \multirow{3}{*}{2.8436176} \\
\hline & borehole & 15 & 20.300000 & & \\
\hline & WHO Standard & 1 & 500.000000 & & \\
\hline \multirow{2}{*}{ Sulphur } & borehole & 15 & 6.910667 & 3.1639069 & .8169172 \\
\hline & WHO Standard & 1 & 200.000000 & & \\
\hline \multirow{2}{*}{ MAGN } & borehole & $0^{a}$ & & & \\
\hline & WHO Standard & 1 & .0500 & & \\
\hline \multirow{2}{*}{ HARDR } & borehole & 15 & 70.53 & 17.884 & 4.618 \\
\hline & WHO Standard & 1 & 100.00 & & \\
\hline \multirow{2}{*}{ NITRAT } & borehole & 15 & 5.511333 & 1.7484641 & .4514515 \\
\hline & WHO Standard & 1 & 3.000000 & & \\
\hline \multirow{2}{*}{ TURB } & borehole & 15 & 7.718667 & .9905112 & .2557489 \\
\hline & WHO Standard & 1 & 500.000000 & & \\
\hline \multirow{2}{*}{ MANG } & borehole & 15 & .058733 & .0270937 & .0069956 \\
\hline & WHO Standard & 1 & .050000 & & \\
\hline \multirow{2}{*}{ COLOUR } & borehole & 15 & 9.53 & 12.961 & 3.346 \\
\hline & WHO Standard & 1 & 20.00 & & \\
\hline \multirow{2}{*}{ POTA } & borehole & 15 & 11.107333 & 4.1030415 & 1.0594008 \\
\hline & WHO Standard & 1 & 12.000000 & & \\
\hline
\end{tabular}

a. $\quad t$ cannot be computed because at least one of the groups is empty.

Source: Analysis by the author, 2021 
Table 2: Statistical analysis of the tested parameters of the fifteen (15) boreholes in the study area and compared with WHO shows that Ph is (.000), B.O.D (.000), TDS (.000), test (000), sulphate (.000), and turbidity (.000)

Independent Samples Test

\begin{tabular}{|c|c|c|c|c|c|c|c|c|}
\hline & & \multicolumn{7}{|c|}{ t-test for Equality of Means } \\
\hline & & \multirow[t]{2}{*}{$\mathrm{T}$} & \multirow[t]{2}{*}{$\mathrm{df}$} & \multirow[t]{2}{*}{ Sig. (2-tailed) } & \multirow[t]{2}{*}{ Mean Difference } & \multirow[t]{2}{*}{$\begin{array}{l}\text { Std. Error } \\
\text { Difference }\end{array}$} & \multicolumn{2}{|c|}{$\begin{array}{l}\text { 95\% Confidence Interval of the } \\
\text { Difference }\end{array}$} \\
\hline & & & & & & & Lower & Upper \\
\hline תח & Equal variances assumed & -.949 & 14 & .359 & -18.7506667 & 19.7605284 & -61.1327850 & 23.6314516 \\
\hline & Equal variances not assumed & 069 & 14 & 946 & $\begin{array}{r}-18.7506667 \\
1453333\end{array}$ & 21164350 & -43939682 & 46846349 \\
\hline $\mathrm{PH}$ & Equal variances not assumed & & & & .1453333 & & T.000000 & \\
\hline BOD & $\begin{array}{l}\text { Equal variances assumed } \\
\text { Equal variances not assumed }\end{array}$ & -4.741 & 14 & .000 & $\begin{array}{l}-3.3873333 \\
-3.3873333\end{array}$ & .7144172 & -4.9196057 & -1.8550609 \\
\hline CHLO & $\begin{array}{l}\text { Equal variances assumed } \\
\text { Equal variances not assumed }\end{array}$ & -87.046 & 14 & .000 & $\begin{array}{l}-240.4026667 \\
-240.4026667\end{array}$ & 2.7617978 & -246.3261338 & -234.4791995 \\
\hline EC & $\begin{array}{l}\text { Equal variances assumed } \\
\text { Equal variances not assumed }\end{array}$ & .544 & 14 & .595 & $\begin{array}{l}40.3900000 \\
40.3900000\end{array}$ & 74.2701619 & -118.9036545 & 199.6836545 \\
\hline TDS & $\begin{array}{l}\text { Equal variances assumed } \\
\text { Equal variances not assumed }\end{array}$ & -2100.679 & 14 & .000 & $\begin{array}{l}-499.5313333 \\
-499.5313333\end{array}$ & .2377952 & -500.0413532 & -499.0213134 \\
\hline FEF & $\begin{array}{l}\text { Equal variances assumed } \\
\text { Equal variances not assumed }\end{array}$ & 1.976 & 14 & .068 & $\begin{array}{l}50.3833333 \\
50.3833333\end{array}$ & 25.4990159 & -4.3066165 & 105.0732832 \\
\hline T.TL & $\begin{array}{l}\text { Equal variances assumed } \\
\text { Equal variances not assumed }\end{array}$ & -42.173 & 14 & .000 & $\begin{array}{l}-479.7000000 \\
-479.7000000\end{array}$ & 11.3744703 & -504.0958125 & -455.3041875 \\
\hline SOLPH & $\begin{array}{l}\text { Equal variances assumed } \\
\text { Equal variances not assumed }\end{array}$ & -59.091 & 14 & .000 & $\begin{array}{l}-193.0893333 \\
-193.0893333\end{array}$ & 3.2676690 & -200.0977862 & -186.0808804 \\
\hline HARDR & $\begin{array}{l}\text { Equal variances assumed } \\
\text { Equal variances not assumed }\end{array}$ & -1.595 & 14 & .133 & $\begin{array}{l}-29.467 \\
-29.467\end{array}$ & 18.471 & -69.082 & 10.149 \\
\hline NITRAT & $\begin{array}{l}\text { Equal variances assumed } \\
\text { Equal variances not assumed }\end{array}$ & 1.391 & 14 & .186 & $\begin{array}{l}2.5113333 \\
2.5113333\end{array}$ & 1.8058059 & -1.3617352 & 6.3844019 \\
\hline TURB & $\begin{array}{l}\text { Equal variances assumed } \\
\text { Equal variances not assumed }\end{array}$ & -481.216 & 14 & .000 & $\begin{array}{l}-492.2813333 \\
-492.2813333\end{array}$ & 1.0229955 & -494.4754405 & -490.0872261 \\
\hline MANG & $\begin{array}{l}\text { Equal variances assumed } \\
\text { Equal variances not assumed }\end{array}$ & .312 & 14 & .760 & $\begin{array}{l}.0087333 \\
.0087333\end{array}$ & .0279822 & -.0512826 & .0687492 \\
\hline COLOUR & $\begin{array}{l}\text { Equal variances assumed } \\
\text { Equal variances not assumed }\end{array}$ & -.782 & 14 & .447 & $\begin{array}{l}-10.467 \\
-10.467\end{array}$ & 13.386 & -39.176 & 18.243 \\
\hline POTA & Equal variances assumed & -.211 & 14 & .836 & -.8926667 & 4.2376030 & -9.9814212 & 8.1960879 \\
\hline מA & Equal variances not assumed & & & & -.8926667 & & & \\
\hline
\end{tabular}

Source: Analysis by the author, 2021 


\section{CONCLUSION AND RECOMMENDATIONS}

In view of the findings of this research, it is concluded that, underground water quality is better and the quality particularly with respect to feacal coliform count is below the W.H.O permissible limit for domestic purposes. These was conducted to test that the water use in the estate is a good quality and this study has collaborated many results in the literatures are based on the findings from the study stated. The following recommendations were made.

1. Government should provide pipe borne water in the estate which is always treated and tested and is fit for human consumption

2. The inhabitant of the estate should treat their boreholes before use for domestic purposes

3. There is need to create awareness of the hazards of drinking contaminated water and

\section{REFERENCES}

[1] World Health Organization. Guideline, standards and health assessment of risk management for water related infectious diseases. Geneva, Switzerland; world health organization, 2015

[2]. I. O. Ebin. Seasonal variations of streams and ground water quality, using quality index. International journal of scientific and engineering research Vol. 10 No.7 pp.170179. 2019

[3]. United Nations. Human Rights to Water and Sanitation, assessed online at ww.unwater.org/waterfacts/human-rights, 2021

[4] I. J. Ekpoh, O. I. Ebin and J. Efiong. Impact of human activities on lokpoi stream in Yakurr Local Government Area, Cross River State, Nigeria. Multi-disciplinary journal of research and development perspective Vol. 1 No. 1, pp. 1-22, 2012

[5] O. I. Ebin. Domestic water quality in relation to water borne diseases in Yakurr Local Government Area, Cross River State Nigeria. Unpublished Ph.D thesis University of Calabar, 2016 the people should be trained on how to treat water before use for domestic purposes

4. Health education officer should be deployed in the area to educate the people on the dangers of having content with contaminated water.

\section{Acknowledgment}

Though the authors did not receive any specific grant from funding agencies in the public, commercial, or not-for-profit sectors, a lot of other auxiliary supports were received. Special thanks to the management and residents of E-one estate in Lemna, being the study area. Special appreciation also goes to the Geographic Information Systems laboratory of the Department of Geography and Environmental Science, University of Calabar, for providing the digital atmosphere for this research.

[6] M. A. Abua and O. A. Ajake/ Water quality status around animal dung in Achabo river catchment of Odukpani Local Government Area of Cross River State Nigeria. International Journal of Bioscience Vol. 4 No. 4 pp. $28-43,2014$

[7]. E. I. Eja. Evaluating the activities of festival on surface water quality in Ugep Cross River State Nigeria. Journal of science studies Vol. 6 No. 2 pp. 2329 - 9150, 2019

[8]. World Health Organization (WHO) and The United Nations Children's Fund (UNICEF).Global Water Supply and Sanitation Assessment Report, 2000.

[9] O. I. Ebin, J. Efiong and R. Odunsi. Geospatial analysis of the occurrence of water borne disease across Yakurr Local Government Area, Cross River State, Nigeria. International journal of scientific \& engineering research vol. 10 No.8. pp. 678695, 2019

[10]. Alpha. Standard methods for the examination of water and waste water $\left(7^{\text {th }}\right.$ ed.) Washington DC: America public Health Association pp. 1134, 2015 